$$
\begin{gathered}
\text { UNIVERSIDADE DE SÃO PAULO } \\
\text { INSTITUTO DE RELAÇÕES INTERNACIONAIS }
\end{gathered}
$$

BRUNO YOUSSEF YUNEN ALVES DE LIMA

\title{
À margem da OMC: a emergência dos padrões privados no comércio internacional
}

(Versão simplificada) 


\section{BRUNO YOUSSEF YUNEN ALVES DE LIMA}

\section{À margem da OMC: a emergência dos padrões privados no comércio internacional}

Dissertação apresentada ao Programa de Pós-Graduação em Relações Internacionais do Instituto de Relações Internacionais da Universidade de São Paulo, para a obtenção do título de Mestre em Ciências.

Orientador: Prof. Dr. Yi Shin Tang

Versão simplificada 


\section{Resumo}

Autor: Bruno Youssef Yunen Alves de Lima

Título: À margem da OMC: a emergência dos padrões privados no comércio internacional

O comércio internacional contemporâneo caracteriza-se pela perda de importância relativa das medidas de natureza tarifária e pela crescente relevância simultaneamente assumida por exigências regulatórias (técnicas, sanitárias e fitossanitárias) de caráter não tarifário. A profusão dessas medidas, destinadas a estabelecer características de produtos ou processos e métodos de produção, é beneficiada pelo protagonismo assumido pelos agentes de mercado, empenhados em impor, à revelia do sistema multilateral de comércio, um arcabouço regulatório distinto, tematicamente mais amplo e geograficamente mais fragmentado. A emergência de uma governança, promovida por uma constelação de agentes privados interessados na determinação dessas medidas, rivaliza, portanto, com a tradicional liderança exercida pelos Estados, cuja atuação está circunscrita aos limites impostos pelos acordos da Organização Mundial do Comércio (OMC). Nesse contexto, o presente trabalho sustenta que a transferência gradual de responsabilidade pelo controle do espaço regulatório a fontes não tradicionais de poder, tais como os agentes de mercado, representa uma escolha voluntária e refletida dos Estados, ainda que sob pena de esvaziamento da arena multilateral como espaço exclusivo de construção de regras. Embora esta calibrada fragilização da organização aparente representar um risco ao próprio sistema internacional de comércio, tal deflexão acaba por assegurar aos Estados o espaço político requerido para acomodações de poder, com simultânea preservação dos ganhos auferidos em outras esferas da agenda multilateral.

Palavras-chave: Padrões privados. Governança internacional. Sistema multilateral de comércio. Organização Mundial do Comércio. OMC. 


\section{Abstract}

Author: Bruno Youssef Yunen Alves de Lima

Title: Beyond the fringe of the WTO: the rise of private standards in international trade

Contemporary international trade is characterized by the loss of relative importance of tariff measures and the growing relevance of non-tariff regulatory requirements (technical, sanitary and phytosanitary). The profusion of these measures, designed to establish characteristics of products or processes and production methods, benefits from the leading role played by market players, who are committed to impose, in default of the multilateral trading system, a distinct, thematically broader and geographically more fragmented regulatory framework. The emergence of a new governance, led by a constellation of private agents interested in the creation of these measures, therefore rivals the traditional leadership exercised by States, whose performance is limited to the limits imposed by the World Trade Organization (WTO) agreements. In this context, the present paper argues that the gradual transfer of responsibility for the control of the regulatory space to non-traditional sources of power, such as market agents, represents a voluntary and reflected choice of States, although it may happen under penalty of emptying the multilateral arena as an exclusive rule-making space. While this calibrated weakening of the organization seems to pose a risk to the international trading system, such a deflation ultimately provides States with the policy space required for power accommodation, with simultaneous preservation of gains earned in other spheres of the multilateral agenda.

Keywords: Private standards. International governance. Multilateral trading system. World Trade Organization. WTO. 